Motivasi Dan Pelatihan Kerja Sebagai Determinan Dalam Kualitas

Pelayanan Publik Pada Rumah Sakit Dr. Esnawan Antariksa

Lanud Halim Perdanakusuma

ISSN : $1412-629 X$

\title{
MOTIVASI DAN PELATIHAN KERJA SEBAGAI DETERMINAN DALAM KUALITAS PELAYANAN PUBLIK PADA RUMAH SAKIT DR. ESNAWAN ANTARIKSA LANUD HALIM PERDANAKUSUMA
}

\section{ARIEF TRI BAWANTO, SUPRIHATI}

STIE AAS Surakarta

Email : suprihati18@yahoo.co.id

Teknik pengambilan sampel yang dipakai dalam penelitian ini penulis menggunakan teknik penelitian Random Sampling (pegawai dan masyarakat) di jadikan sampel diambil secara acak.

Berdasarkan hasil analisis Regresi di peroleh $\mathrm{Y}=10,786+0,446 \mathrm{X} 1+0$, koefisien korelasi parsial bernilai positif antara variabel Motivasi Kerja terhadap variabel Kualitas Pelayanan Publik diperoleh nilai sebesar 0,743 sehingga dapat disimpulkan bahwa pengaruhnya kuat. Dibuktikan melalui hasil uji hipotesis yang diperoleh dengan nilai $t_{\text {hitung }}$ sebesar $=2,507>t_{0,05}(64)=1,670$, maka $\mathrm{H}_{\mathrm{o}}$ ditolak dan $\mathrm{H}_{\mathrm{a}}$ diterima yang berarti mempunyai cukup bukti bahwa antara variabel Motivasi Kerja terhadap variabel Kualitas Pelayanan Publik ada pengaruh yang signifikan. Berdasarkan hasil analisis koefisien korelasi parsial bernilai positif antara variabel Pelatihan terhadap variabel Kualitas Pelayanan Publik diperoleh nilai sebesar 0,893 sehingga dapat disimpulkan pengaruhnya sangat kuat. Dibuktikan melalui hasil uji hipotesis variabel Pelatihan yang diperoleh yakni karena nilai thitung $=8,784>\mathrm{t}_{0,05}(64)=1,670$, maka $\mathrm{H}_{\mathrm{o}}$ ditolak dan $\mathrm{H}_{\mathrm{a}}$ diterima yang berarti mempunyai bukti, bahwa antara variabel Pelatihan terhadap variabel Kualitas Pelayanan Publik ada pengaruh signifikan. Berdasarkan hasil analisis secara simultan variabel Motivasi Kerja dan Pelatihan terhadap Kualitas Pelayanan Publikyang menghasilkan model Summary atau nilai R sebesar 0,894 memiliki nilai positif dan tingkat pengaruh sangat kuat sedangkan nilai R Square sebesar 0,798 atau $79,8 \%$ hal ini dinyatakan kedua variabel independen tersebut dapat mempengaruhi variabel

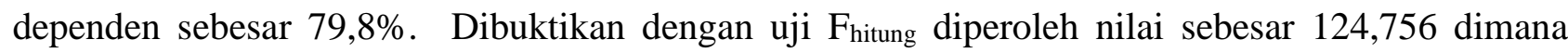
lebih besar dari $F_{\text {tabel }}(65)$ sebesar 2,750 dengan tingkat signifikan sebesar 0,000 karena 0,000<0,05, maka dapat dikatakan variabel Motivasi Kerja dan Pelatihan secara bersama-sama berpengaruh positif terhadap Kualitas Pelayanan Publik pada Rumah Sakit dr. Esnawan Antariksa Lanud Halim Perdanakusuma.

Kata kunci : Motivasi, pelatihan kerja,Kualitas pelayanan Publik. 


\section{PENDAHULUAN}

Pada masa era modern seperti ini perkembangan teknologi juga alat komunikasi dari berbagai merk yang serba canggih tersebut memamerkan kecanggihan masing-masing merk produk unggulannya. Dengan demikian setiap organisasi pasti membutuhkan sumber daya manusia yang benar-benar berkualitas baik dan profesonalisme dibidangnya masing-masing. Dari permasalahan tersebut di atas sumber daya manusia memegang peranan yang sangat dominan dalam segala hal pekerjaan dan motivasi kerjanya harus lebih tinggi, karena sumber daya manusia diharapkan dapat memanfaatkan potensi-potensi yang ada dalam dirinya sendiri seraca optimal mungkin dimasa mendatang harus dapat meningkatkan kualitas pelayanan publik sebagaimana yang diharapkan pimpinan organisasi. Dengan berkembangan taknologi yang semakin cepat makanya sumber daya manusia mempunyai peran penting untuk menunjang pembangunan dalam kehidupan, terutama dalam perbaikan sikap, pandangan dan norma-norma baru dalam kehidupan seseorang, keluarga maupun bangsa dan negara. Karena maju mundurnya suatu bangsa, masyarakat atau keluarga itu ditentukan oleh kemajuan zaman itu sendiri di masa yang akan datang.

Pada saat ini motivasi kerja pegawai pada Rumah Sakit dr. Esnawan Antariksa Lanud Halim Perdanakusuma terlihat masih rendah dan belum sesuai apa yang harapan pimpinan. Maka seorang pimpinan mengharapkan motivasi kerja agar lebih baik memang sangat diharapkan karena apabila motivasi kerja pegawainya tinggi akan sangat mempengaruhi tingkat Kualitas Pelayanan Publik yang diberikan pada masyarakat yang membutuhkan jasa kesehatan. Motivasi (motivation) hanya ditujukan pada sumber daya manusia umumnya dan bawahan khususnya pegawai. Aspek penting dalam meningkatkan motivasi kerja pada bawahan atau pegawai, pemimpin pada Rumah Sakit dr. Esnawan Antariksa Lanud Halim Perdanakusuma hendaknya dapat memberikan motivasi searah dan sesuai dengan karakteristik yang ada di bawahan atau pegawai. Motivasi kerja adalah untuk memberikan dorongan dan usaha untuk mencapai pemuasan keinginan dan sasaran setiap pegawai pada Rumah Sakit dr. Esnawan Antariksa Lanud Halim Perdanakusuma. Pemuasan dimaksudkan untuk merasakan kesenangan atau kebahagiaan apabila suatu keinginan telah dapat dicapai. Jadi jelas bahwa seorang pegawai harus memiliki motivasi kerja yang tinggi agar dapat mencapai tujuan dengan mudah dan sesuai apa yang diharapkannya. Ditinjau dari perannya ada dua macam motivasi, yaitu motivasi positif dan motivasi negatif. Motivasi positif adalah motivasi yang menimbulkan harapan yang bersifat menguntungkan atau menggembirakan bagi pegawai misalnya : gaji, fasilitas, karier, jaminan hari tua dan sebagainya. Motivasi negatif adalah yang menimbulkan rasa takut misalnya ancaman, tekanan, intimidasi dan sejenisnya yang sifatnya merugian pegawai.

Pelatihan merupakan unsur kunci yang pada hakekatnya adalah proses pembelajaran bagi setiap pegawai baru maupun pegawai seniyor untuk meningkatkan kemampuan ataupun keterampilannya. Untuk melatih pegawai, dibutuhkan tentang bagaimana orang belajar yang berhasil guna. Pegawai dalam suatu organisasi sebagai sumber daya manusia dan sebagai hasil dari proses seleksi harus dikembangkan agar kemampuan ataupun keterapilan mereka 
$629 X$

dapat mengikuti perkembangan organisasi. Didalam suatu organisasi, unit atau bagian yang mempunyai tugas untuk pengembangan tenaga ini biasanya adalah unit pelatihan pegawai. Pelatihan membantu pegawai dalam memahami suatu pengetahuan praktis dan penetapannya, guna meningkatkan keterampilan, kecakapan dan sikap yang diperlakukan oleh organisasi dalam mencapai tujuannya.

Pelatihan kerja pegawai pada Rumah Sakit dr. Esnawan Antariksa Lanud Halim Perdanakusuma sampai saat ini masih terlihat belum optimal dijalankan dan sangat perlu peningkatan program pelatihan secara bersama-sama pegawai baru juga pegawai seniyornya agar kedepannya seluruh pegawai yang berkualitas baik. Pelatihan sesungguhnya berhubungan dengan peningkatkan ilmu pengetahuan, kecerdasan, pengetahuan dan kemampuan yang lebih tinggi pelatihan lebih bersifat praktis. Pelatihan baik di organisasi sangat diharapkan, sehingga program pelatihan dapat diikuti dengan mudah oleh para pegawai yang ingin menambah ilmu pengetahuannya. Meskipun kemajuan program pelatihan sudah berkembang sangat pesat, tetapi program pelatihan tidak hanya terbatas pada pegawai baru saja melainkan setiap pegawai diberikan kesempatan untuk mengikutinya. Keinginan serta tingkat keterampilan sangat diperlukan maka diperlukan prinsip-prinsip tertentu dalam manajemen sumber daya manusia, di antaranya adalah mengefektifkan program pelatihan agar tenaga kerja dapat terarah, dibina dan ditingkatkan pengetahuannya supaya dapat mengikuti perkembangan teknologi sesuai dengan tujuan organisasi.

Kualitas pelayanan publik pada Rumah Sakit dr. Esnawan Antariksa Lanud Halim Perdanakusuma sampai saat ini masih terlihat belum optimal dan sangat perlu peningkatan oleh pimpinan bersama-sama pegawainya. Kualitas pelayanan publik pada Rumah Sakit dr. Esnawan Antariksa Lanud Halim Perdanakusuma dipengaruhi oleh banyak faktor, pemberian motivasi kerja, peningkatan gaji berdasarkan atau sesuai dengan beban kerja (job description) dan lain sebagainya. Kualitas pelayanan publik merupakan suatu ukuran dari output produk dan jasa dibandingkan dengan input kerja, bahan-bahan, dan peralatan. Peningkatan kualitas pelayanan publik bukan berarti para pegawai bekerja lebih keras, tetapi pegawai harus bekerja lebih cepat dan tepat sehingga akan menghasilkan hasil kerja yang lebih otimal sebagaimana yang diharapkan. Selain itu peningkatan kualitas pelayanan publik sangat dipengaruhi oleh program pembinaan, pendidikan dan pelatihan yang diberikan setiap pegawainya agar dikemudian hari dapat meningkatkan kualitas pelayanan publik.

Kualitas pelayanan publik pada Rumah Sakit dr. Esnawan Antariksa Lanud Halim Perdanakusuma harus diciptakan sebaik-baiknya supaya moral kerja, dedikasi, kecintaan dan kedisiplinan pegawai akan lebih meningkat. Peningkatan kualitas pelayanan publik harus dirasakan sebagai tanggung jawab dan perlu diyakini sebagai kepentingan bersama, sebab tinggi rendahnya kualitas pelayanan publik pada Rumah Sakit dr. Esnawan 
Antariksa Lanud Halim Perdanakusuma tidak saja menyangkut hasil pekerjaan yang dicapainya, tetapi menyangkut kelangsungan hidup organisasi itu sendiri di masa mendatang. Untuk merealisasikan tujuan tersebut organisasi ini maka pimpinan harus mengambil langkah-langkah, antara lain memilih alternatif kegiatan yang akan dilaksanakan atau diusahakan dengan melihat kemungkinan kesempatan baik atau jangka pendek, menetapkan kebijaksanaan, selanjutnya menata struktur organisasi dan struktur tugas yang merupakan alat untuk melaksanakan rencana kerja yang telah ditetapkan semula. Dengan demikian

Dengan Kualitas Pelayanan Publik lebih baik merupakan tingkat keberhasilan yang dicapai seorang pegawai untuk mengetahui sejauh mana seorang pegawai mencapai kualitas pelayanan publik di masa yang akan dating dan diukur atau dinilai secara keseluruhan. Kualitas pelayanan publik yang baik dalam suatu organisasi akan memberi jaminan demi tercapainya tujuan sebagaimana yang diharapkan pimpinan.

\section{Perumusan Masalah}

1. Seberapa besarkah pengaruh Motivasi Kerja terhadap Kualitas Pelayanan Publik Pada Rumah Sakit dr. Esnawan Antariksa Hanud Halim Perdanakusuma?

2. Seberapa besarkah pengaruh Pelatihan terhadap Kualitas Pelayanan Publik Pada Rumah Sakit dr. Esnawan Antariksa Hanud Halim Perdanakusuma?
3. Secara simultan seberapa besarkah pengaruh Motivasi Kerja dan Pelatihan terhadap Kualitas Pelayanan Publik Pada Rumah Sakit dr. Esnawan Antariksa Hanud Halim Perdanakusuma?

Tujuan Penelitian

1. Untuk mengetahui seberapa besarkah pengaruh Motivasi Kerja terhadap Kualitas Pelayanan Publik Pada Rumah Sakit dr. Esnawan Antariksa Lanud Halim Perdanakusuma.

2. Untuk mengetahui seberapa besarkah pengaruh Pelatihan terhadap Kualitas Pelayanan Publik Pada Rumah Sakit dr. Esnawan Antariksa Lanud Halim Perdanakusuma.

3. Untuk mengetahui secara simultan seberapa besarkah pengaruh Motivasi Kerja dan Pelatihan terhadap Kualitas Pelayanan Publik Pada Rumah Sakit dr. Esnawan Antariksa Lanud Halim Perdanakusuma.

\section{Penelitian Terdahulu}

Penelitian yang dilakukan oleh Agus Tahyani (2014) tentang "Pengaruh Profesionalisme dan Motivasi Terhadap Kualitas Pelayanan Publik Pada Dinas Tata Ruang Kabupaten Tangerang”. Berpengaruh positif variabel Profesionalisme terhadap variabel Kualitas Pelayanan Publik diperoleh nilai sebesar 0,764 atau 58,4\% sehingga dapat disimpulkan bahwa hasil analisis bernilai positif dan pengaruhnya kuat. Hal tersebut diperlukan pembuktian dengan uji hipotesis diperoleh nilai $\mathrm{t}_{\text {hitung }}$ sebesar $=7,636>\mathrm{t}_{0,05}(105)=$ 1,645, maka $\mathrm{H}_{\mathrm{o}}$ ditolak dan $\mathrm{H}_{\mathrm{a}}$ diterima berarti mempunyai cukup 
bukti ada pengaruh signifikan. Berdasarkan pada hasil analisis koefisien korelasi parsial antara variabel Motivasi terhadap Kualitas Pelayanan Publik diperoleh nilai sebesar 0,689 atau $47,5 \%$ sehingga dapat disimpulkan bahwa hasil analisis bernilai positif dan pengaruhnya kuat. Hal tersebut diperlukan pembuktian dengan uji hipotesis variabel Motivasi diperoleh nilai $\mathrm{t}_{\text {hitung }}=10,440>\mathrm{t}_{0,05}$ (105) $=1,645$, maka $\mathrm{H}_{\mathrm{o}}$ ditolak dan $\mathrm{H}_{\mathrm{a}}$ diterima yang berarti mempunyai bukti, bahwa antara variabel Motivasi terhadap variabel Kualitas Pelayanan Publik ada pengaruh signifikan. Hasil secara simultan variabel Profesionalisme dan Motivasi terhadap variabel Kualitas Pelayanan Publik diperoleh model Summary nilai $\mathrm{R}$ sebesar 0,836 dan sedangkan nilai $\mathrm{R}$ Square sebesar 0,698 atau 69,8\%, bernilai positif dan pengaruh sangat kuat. Hal tersebut diperkuat juga dengan uji ANOVA atau $F_{\text {hitung }}$ di peroleh nilai sebesar 368,969 dimana lebih besar dari $F_{\text {tabel }}$ (106) sebesar 2,700 dengan tingkat signifikan sebesar 0,000 karena 0,000 < 0,05, maka dapat dikatakan secara bersamasama berpengaruh signifikan.

Penelitian yang dilakukan oleh M. Iqbal (2013) tentang "Pengaruh Pengawasan Intern dan Budaya Kerja Terhadap Kualitas Pelayanan Perijinan Pemanfaatan Ruang Pada Badan Pelayanan Perijinan Terpadu Kabupaten Tangerang". Hasil penelitian menunjukkan bahwa terdapat pengaruh positif variabel Pengawasan Intern terhadap variabel Kualitas Pelayanan Perijinan Pemanfaatan Ruang sebesar 57.8\%. Sedangkan hasil uji hipotesis yang diperoleh dengan nilai thitung sebesar $=$ $5.569>\mathrm{t}_{0,05}{ }_{(138)}=1.656$, maka terdapat cukup bukti bahwa antara variabel Pengawasan Intern terhadap variabel Kualitas Pelayanan Perijinan Pemanfaatan Ruang (Y) terdapat pengaruh signifikan. Terdapat pengaruh positif variabel Budaya Kerja terhadap variabel Kualitas Pelayanan Perijinan Pemanfaatan Ruang (Y) sebesar 62.3\%. Dan hasil uji hipotesis variabel Budaya Kerja yang diperoleh yakni karena nilai thitung $=7.127>\mathrm{t}_{0,05}(138)=1.656$, maka terdapat bukti, bahwa antara variabel Budaya Kerja $\left(\mathrm{X}_{2}\right)$ terhadap variabel Kualitas Pelayanan Perijinan Pemanfaatan Ruang (Y) terdapat pengaruh yang nyata dan signifikan. Secara simultan terdapat pengaruh positif antara variabel independen Pengawasan Intern $\left(\mathrm{X}_{1}\right)$ dan Budaya Kerja terhadap variabel dependen Kualitas Pelayanan Perijinan Pemanfaatan Ruang sebesar 69.2\%. Sedangkan hasil uji ANOVA atau Fhitung di dapat nilai sebesar 153.998 dimana > dari $F_{\text {tabel (139) }}$ sebesar 3.06, maka dapat dikatakan variabel Pengawasan Intern $\left(\mathrm{X}_{1}\right)$ dan variabel Budaya Kerja secara bersama-sama terdapat pengaruh sangat signifikan dengan variabel Kualitas Pelayanan Perijinan Pemanfaatan Ruang.

Penelitian yang dilakukan oleh Ratih Dwiaryanti P. (2012) tentang "Pengaruh Kompetensi dan Sarana Kerja Terhadap Kualitas Pelayanan Publik Pada Rumah Sakit DR. Sitanala Tangerang". Hasil penelitian menunjukkan bahwa terdapat pengaruh positif variabel Kompetensi 
$\left(\mathrm{X}_{1}\right)$ terhadap variabel Kualitas Pelayanan Publik (Y) sebesar 52.7\%. Sedangkan hasil uji hipotesis yang diperoleh dengan nilai thitung sebesar $=$ $25.422>\mathrm{t}_{0,05}{ }_{(223)}=1.652$, terdapat pengaruh signifikan. Terdapat pengaruh positif variabel Sarana Kerja $\left(\mathrm{X}_{2}\right)$ terhadap variabel Kualitas Pelayanan Publik (Y) sebesar 63.2\%. Dan hasil uji hipotesis variabel Sarana Kerja $\left(\mathrm{X}_{2}\right)$ yang diperoleh yakni karena nilai $t_{\text {hitung }}=29.949>\mathrm{t}_{0,05}$ (223) $=1.652$, maka terdapat pengaruh yang nyata dan signifikan. Secara simultan terdapat pengaruh positif antara variabel independen Kompetensi $\left(\mathrm{X}_{1}\right)$ dan Sarana Kerja $\left(\mathrm{X}_{2}\right)$ sebesar $90.6 \%$, jadi kedua variabel independen tersebut dapat saling berpengaruh dengan variabel dependen Kualitas Pelayanan Publik sebesar 90.6\%. Sedangkan hasil uji ANOVA atau $F_{\text {test }}$ atau $F_{\text {hitung }}$ di dapat nilai sebesar 1069.926 dimana $>$ dari $F_{\text {tabel }}(2,222)$ sebesar 3.04 dengan tingkat signifikan sebesar 0,000 karena $0,000<0,05$, maka dapat dikatakan variabel Kompetensi $\left(\mathrm{X}_{1}\right)$ dan variabel Sarana Kerja $\left(\mathrm{X}_{2}\right)$ secara bersama-sama terdapat pengaruh sangat signifikan dengan variabel Kualitas Pelayanan Publik (Y) di Rumah Sakit DR. Sitanala Tangerang.

\section{TINJAUAN PUSTAKA}

Manajemen Sumber Daya Manusia mula-mula disebut manajemen personalia, namun pada masa sekarang ini istilah manajemen personalia telah banyak digantikan dengan istilah manajemen Sumber Daya Manusia.. Hal ini disebabkan terbatasnya kemampuan, sehingga dalam usaha untuk memenuhi kebutuhan hidupnya diperlukan suatu kerjasama antar individu yang satu dengan lainnya.

Manajemen sumber daya
manusia, terlebih dahulu harus
mengetahui pengertian tentang manajemen itu sendiri. Manajemen sebenarnya sudah ada sejak dahulu kala, sejak manusia mengelompokkan diri untuk mencapai tujuan melalui kelompok yang tidak dapat dicapai secara individu. Sumber daya manusia dimaksud tidak lain orang-orang yang menyediakan tenaga, bakat, kreativitas dan semangatnya bagi organisasi. Dalam lingkup organisasi sumber daya manusia tersebut terdiri dari Karyawan dan manajer. Tanpa orang yang berkompeten, setiap organisasi atau organisasi akan menemui kesukaran dalam mencapai tujuan.

Pelatihan merupakan unsur kunci yang pada hakekatnya adalah proses pembelajaran bagi setiap pegawai baru maupun pegawai seniyor untuk meningkatkan kemampuan ataupun keterampilannya. Untuk melatih pegawai, dibutuhkan tentang bagaimana orang belajar yang berhasil guna. Pegawai dalam suatu organisasi sebagai sumber daya manusia dan sebagai hasil dari proses seleksi harus dikembangkan agar kemampuan ataupun keterapilan mereka dapat mengikuti perkembangan organisasi. Didalam suatu organisasi, unit atau bagian yang mempunyai tugas untuk pengembangan tenaga ini biasanya adalah unit pelatihan pegawai. Pelatihan membantu pegawai dalam memahami suatu pengetahuan praktis dan penetapannya, guna meningkatkan keterampilan, kecakapan dan sikap yang 
diperlakukan oleh organisasi dalam mencapai tujuannya.

Menurut pendapat Herzberg dalam Malayu SP. Hasibuan (2007 : 156), menyatakan bahwa Teori motivasi mempunyai sub variabel yaitu : Motif, Harapan dan insentif, adapun pengertiannya adalah : a) Motif (Motif) adalah suatu perangsang keinginan (want) dan daya penggerak kemauan bekerja seseorang. Setiap motif mempunyai tujuan tertentu yang ingin dicapai. b) Harapan (Expectancy) adalah : suatu kesempatan yang diberikan terjadi karena perilaku untuk tercapainya tujuan. c) Insentif (Incentive) yaitu memotivasi (merangsang) bawahan dengan memberikan hadiah (imbalan) kepada mereka yang berprestasi di atas prestasi standar. Dengan demikian semangat kerja bawahan akan meningkat karenan umumnya manusia senang menerima yang baik-baik saja"

Menurut pendapat Fillmorre H. Stanford dalam Anwar Prabu Mangkunegara (2009 : 93) mengemukakan bahwa :"Motivation as an energizing condition of the organism that serves to direct that organism toward the goal of a certain class" (motivasi sebagai suatu kondisi yang menggerakkan manusia ke arah suatu tujuan tertentu).

Menurut Stoner dan Freeman (2009 : 56), mengemukakan pengertian motivasi kerja bahwa: "Motivasi adalah karakteristik psikologis pada aktifitas manusia untuk memberi kontribusi berupa tingkat komitmen seseorang termasuk faktor-faktor yang menyebabkan, menyalurkan dan mempertahankan tingkah laku manusia dalam arah tekad tertentu untuk mencapai keinginan. Aktifitas yang dilakukan adalah aktifitas yang bertujuan agar terpenuhi keinginan individu".

Dari pengertian diatas dapat dinyatakan bahwa motivasi dikatakan sebagai kecenderungan untuk beraktivitas yang bersumber dari dalam diri dengan membangkitkan dan mengarahkan perilaku atau tindakan yang berhubungan tujuan dan pencapaian rasa puas. Biasanya motivasi tersebut meningkat sejalan dengan meningkatnya kebutuhan yang harus dipenuhi

Pelatihan adalah suatu kegiatan dalam kaitan dengan aktivitas pengembangan diri. Latihan membantu para pegawai dalam memahami suatu pengetahuan praktis dan penerapannya, guna meningkatkan keterapilan, kecakapan dan sikap yang diperlakukan oleh organisasi dalam mencapai tujuannya.

Menurut Gary Dessler (2007 : 266) mengemukakan pengertian pelatihan bahwa : "Pelatihan merupakan unsur kunci yang pada hakekatnya adalah proses pembelajaran. Untuk melatih pegawai, dibutuhkan tentang bagaimana orang belajar. Pegawai dalam suatu organisasi sebagai SDM, dan sebagai hasil dari proses seleksi harus dikembangkan agar kemampuan mereka dapat mengikuti perkembangan organisasi. Didalam suatu organisasi, unit atau bagian yang mempunyai tugas untuk pengembangan tenaga ini biasanya adalah unit pelatihan pegawai".

Menurut pendapat Malayu SP. Hasibuan (2007 : 78) mengemukakan 
pengertian pelatihan bahwa :"Pelatihan adalah bagian pendidikan yang menyangkut proses belajar untuk memperoleh dana dan meningkatkan keterampilan di luar sistem pendidikkan yang berlaku, dalam waktu yang relatif singkat dan metode yang lebih mengutamakan praktek dari pada teorinya".

\section{Pengertian Kualitas Pelayanan Publik}

Pelayanan yang berkualitas dalam arti pemberian layanan sederhana, mudah, dan dilakukan secara wajar dan profesional pada satu sisi, dan perkembangan masyarakat yang sangat dinamis, tingkat kehidupan masyarakat yang semakin baik, merupakan indikasi dari pemberdayaan (empowering) yang dialami oleh masyarakat disisi lainnya.

Menurut Feisal Tamin (2009: 65) mengemukakan pengertian pelayanan publik bahwa :"Pelayanan publik yang profesional setidak tidaknya harus mencerminkan akuntabilitas dan responsibilitas. Untuk dapat memberikan pelayanan publik yang baik maka aparat pemerintah perlu memahami prinsip prinsip pelayanan yang baik yaitu kesederhanaan, kejelasan, kepastian waktu, akurasi serta kenyamanan. Profesionalisme aparat dalam memberikan pelayanan dengan sendirinya akan menggambarkan citra pelayanan yang diberikan kepada publik."

Menurut Roth Gabriel dalam Bambang Istianto, (2011: 106) mengemukakan Pengertian pelayanan publik bahwa : Any Service available to the public whether provided publicly (as is a museum) or privately (as is a retaurant). Pelayanan Publik merupakan suatu pelayanan yang telah disediakan jika untuk kepentingan publik di sediakan oleh pemerintah contohnya "museum" atau untuk pribadi yang menyediakan yaitu swasta contohnya "restourant".

\section{Pengertian Motivasi Kerja}

Setiap orang dalam hidupnya memerlukan kebutuhan, baik kebutuhan jasmani maupun rohani. Dengan adanya kebutuhan tersebut akan mendorong adanya rangsangan (stimulasi) dan tingkah laku balas (respon). Motivasi kerja memang merupakan suatu hal yang sangat penting dalam suatu organisasi. Disatu pihak motivasi mempunyai peranan yang sangat penting bagi setiap unsur pimpinan sedang dipihak lain motivasi merupakan suatu hal yang dirasakan sulit oleh para pemegang jabatan. Oleh karena itu, setiap pimpinan perlu memahami apa arti hakikat motivasi, teori motivasi, dan yang tidak kalah pentingnya ialah mengetahui kelompok bawahan yang perlu dimotivasi. Menurut pendapat Maslow dalam Susilo Martoyo (2005 : 164) mengemukakan pengertian motivasi bahwa : Motivasi berasal dari kata latin movere yang berarti dorongan atau menggerakkan. Motivasi (motivation) dalam manajemen hanya ditujukan pada sumber daya manusia umumnya dan bawahan khususnya. Motivasi mempersoalkan bagaimana caranya mengarahkan daya dan potensi bawahan, agar mau bekerjasama secara produktif berhasil mencapai dan mewujudkan tujuan yang telah ditentukan. Menurut para ahli seperti Gouzali Saydam (2006 : 
Motivasi Dan Pelatihan Kerja Sebagai Determinan Dalam Kualitas

Pelayanan Publik Pada Rumah Sakit Dr. Esnawan Antariksa

Lanud Halim Perdanakusuma

ISSN : 1412-

$629 \mathrm{X}$

165) mengemukakan pengertian motivasi

bahwa : Motivasi adalah kondisi mental yang mendorong dilakukannya suatu tindakan (action atau activities) dan memberikan kekuatan (energy) yang mengarah kepada pencapaian kebutuhan, memberi kepuasan ataupun mengurangi ketidakseimbangan. Menurut pendapat Sedarmayanti (2008 : 104) mengemukakan motivasi kerja adalah sebagai keseluruhan proses pemberian motif kerja kepada para bawahan sedemikian rupa sehingga mereka mau bekerja dengan iklas demi tercapainya tujuan perusahaan dengan efektif dan efisien.

Menurut Soewarno Handajaningrat (2004 : 83) membedakan antara motivasi dan pemuasan yaitu motivasi dimaksudkan untuk memberikan dorongan dan usaha untuk mencapai pemuasan keinginan dan sasaran sedangkan pemuasan

dimaksudkan untuk merasakan kesenangan atau kebahagiaan apabila suatu keinginan telah dapat dipuaskan".

Menurut Barelson dan Steiner yang dikutip Bedjo Siswanto Sastrohadiwiryo (2005 : 267) mengemukakan bahwa motivasi diartikan sebagai keadaan kejiwaan dan sikap mental manusia yang memberikan energi mendorong kegiatan atau menggerakan dan mengarah atau menyalurkan ke arah mencapai kebutuhan yang memberi kepuasan atau mengurangi ketidak seimbangan. Menurut pendapat Fillmorre H. Stanford dalam Anwar Prabu Mangkunegara (2009 : 93) mengemukakan bahwa :Motivation as an energizing condition of the organism that serves to direct that organism toward the goal of a certain class" (motivasi sebagai suatu kondisi yang menggerakkan manusia ke arah suatu tujuan tertentu).

\section{Kerangka Penelitian}

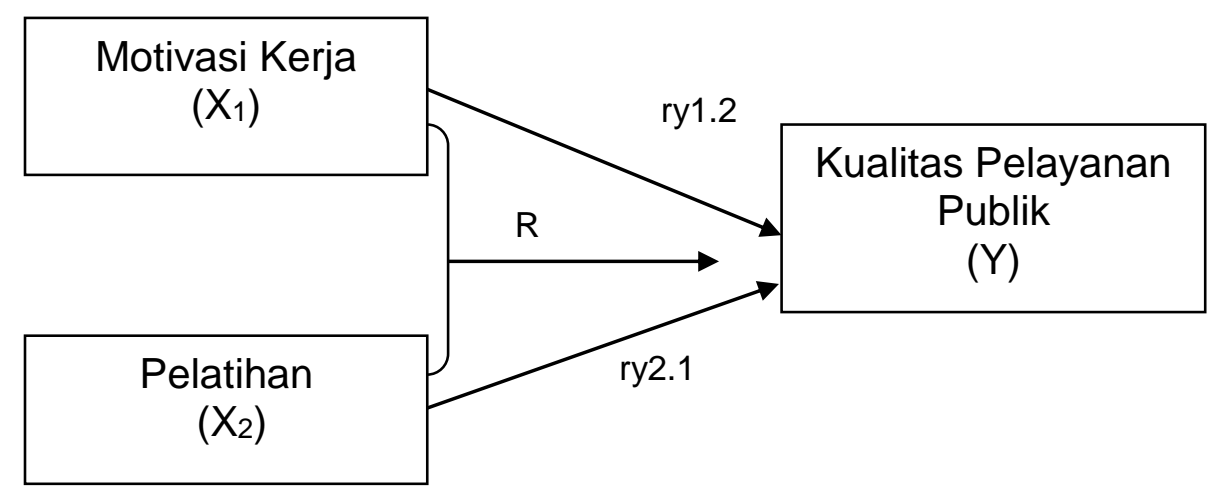

\section{Keterangan :}

$\mathrm{X}_{1}=$ Variabel bebas (Motivasi Kerja)

$\mathrm{X}_{2}=$ Variabel bebas (Pelatihan)

$\mathrm{Y}=$ Variabel terikat (Kualitas Pelayanan Publik). 
ry1.2 = Korelasi Parsial antara variabel Motivasi Kerja terhadap Kualitas Pelayanan Publik. ry2.1 = Korelasi Parsial variabel Pelatihan terhadap Kualitas Pelayanan Publik.

$\mathrm{R}=$ Korelasi secara simultan variabel Motivasi Kerja dan Pelatihan terhadap Kualitas Pelayanan Publik.

\section{Hipotesis}

1. Diduga ada pengaruh positif dan signifikan Motivasi Kerja Terhadap Kualitas Pelayanan Publik pada Rumah Sakit dr. Esnawan Antariksa Lanud Halim Perdanakusuma.

2. Diduga ada pengaruh positif dan signifikan Pelatihan terhadap Kualitas Pelayanan Publik pada Rumah Sakit dr. Esnawan Antariksa Lanud Halim Perdanakusuma.

3. Diduga secara simultan ada pengaruh positif Motivasi Kerja dan Pelatihan terhadap Kualitas Pelayanan Publik pada Rumah Sakit dr. Esnawan Antariksa Lanud Halim Perdanakusuma.

\section{METODE PENELITIAN}

Populasi dan Sampel

Dalam hal ini yang dijadikan populasi adalah semua pegawai yang ada pada Rumah Sakit dr. Esnawan Antariksa Lanud Halim Perdanakusuma yang berjumlah 220 orang . Teknik pengambilan sampel yang dipakai dalam penelitian ini penulis menggunakan teknik sistem Randam Sampling atau metode Acak. Dimana setiap anggota populasi mempunyai peluang yang sama untuk dipilih sebagai sampel. Sampel yang dipakai sebesar $30 \%$ dari populasi yaitu sejumlah 66 orang.

\section{Operasionalisasi Variabel Penelitian}

Variabel-variabel penelitian dapat dijabarkan ke dalam dimensi dan indikator- indikatornya. Dari indikator-indikator tersebut dapat disusun pengukurannya sehingga dengan kuantitatif yang didapat dalam penelitian selanjutnya digunakan sebagai bahan analisis statistik. Sesuai pendapat Sugiyono (2010 : 20) mengenai variabel, menyatakan : "Variabel dapat didefinisikan sebagai atribut dari seseorang atau objek yang mempunyai "variari" antara satu orang dengan orang lain atau satu objek dengan objek yang lain.”

Dalam penelitian ini terdapat tiga variabel yaitu Motivasi Kerja $\left(\mathrm{X}_{1}\right)$ dan Pelatihan $\left(\mathrm{X}_{2}\right)$ sebagai variabel independen sedangkan Kualitas Pelayanan Publik (Y) sebagai variabel dependen, untuk lebih jelasnya, operasionalisasi variabel penelitian yang merupakan indikatorindikator variabel dapat dirumuskan sebagai berikut :

Operasionalisasi Variabel Penelitian

\begin{tabular}{|l|l|l|c|}
\hline \hline VARIABEL & \multicolumn{1}{|c|}{ DIMENSI } & \multicolumn{1}{|c|}{ INDIKATOR } & $\begin{array}{c}\text { No. } \\
\text { Angket }\end{array}$ \\
\hline \hline \multirow{3}{*}{} & a) Motif & 1) Gaji & 1 \\
& & 2) Tunjangan & 2 \\
& & 3) Fasilitas memadai & 3 \\
& & 4) Bekerjasama & 4 \\
\hline
\end{tabular}


Motivasi Dan Pelatihan Kerja Sebagai Determinan Dalam Kualitas

Pelayanan Publik Pada Rumah Sakit Dr. Esnawan Antariksa

Lanud Halim Perdanakusuma

ISSN : 1412-629X

\begin{tabular}{|c|c|c|c|}
\hline $\begin{array}{l}\text { Motivasi Kerja } \\
\qquad\left(\mathrm{X}_{1}\right) \\
\text { Sumber : }\end{array}$ & b) Harapan & $\begin{array}{l}\text { 1) Kerja yang menyenangkan } \\
\text { 2) Rasa ikut memiliki } \\
\text { 3) Disiplin waktu kerja } \\
\text { 4) Arusansi }\end{array}$ & $\begin{array}{l}5 \\
6 \\
7 \\
8\end{array}$ \\
\hline Hasibuan (2007) & c) Insentif & $\begin{array}{l}\text { 1) Intrinsik } \\
\text { 2) Ekstrinsik }\end{array}$ & $\begin{array}{c}9 \\
10\end{array}$ \\
\hline $\begin{array}{l}\text { Pelatihan } \\
\qquad\left(\mathrm{X}_{2}\right)\end{array}$ & $\begin{array}{l}\text { a) Menjalankan } \\
\text { tugas }\end{array}$ & $\begin{array}{l}\text { 1) Bekal pengetahuan } \\
2 \text { Membangkitkan mental } \\
\text { pegawai } \\
\text { 3) Mengembangkan ilmu } \\
\text { 4) Memberikan pengarahan } \\
\text { 5) Keterampilan }\end{array}$ & $\begin{array}{l}1 \\
2 \\
3 \\
4 \\
5\end{array}$ \\
\hline $\begin{array}{l}\text { Sumber: } \\
\text { Hasibuan } \\
(2007)\end{array}$ & $\begin{array}{l}\text { b) Manfaat bagi } \\
\text { pegawai }\end{array}$ & $\begin{array}{l}\text { 1) Semangat kerja } \\
\text { 2) Memberikan prinsip kerja } \\
\text { 3) Mengarahkan tugas pokok } \\
\text { 4) Bekerja dengan baik } \\
\text { 5) Tidak mengalami kesulitan }\end{array}$ & $\begin{array}{l}6 \\
7 \\
8 \\
9 \\
10\end{array}$ \\
\hline & a) $\begin{array}{l}\text { Kemampuan } \\
\text { (Reliability) }\end{array}$ & $\begin{array}{l}\text { 1) Mampu } \\
\text { 2) Bekerja dengan baik }\end{array}$ & $\begin{array}{l}1 \\
2\end{array}$ \\
\hline $\begin{array}{c}\text { Kualitas } \\
\text { Pelayanan Publik }\end{array}$ & $\begin{array}{l}\text { b) Tanggapan } \\
\text { (Responsivenss) }\end{array}$ & $\begin{array}{l}\text { 1) Membantu } \\
\text { 2) Memberikan pelayanan }\end{array}$ & 3 \\
\hline$(\mathrm{Y})$ & $\begin{array}{l}\text { c) Jaminan } \\
\text { (Assurance) }\end{array}$ & $\begin{array}{l}\text { 1) Kemampuan } \\
\text { 2) Kesopanan }\end{array}$ & $\begin{array}{l}5 \\
6\end{array}$ \\
\hline Sumber : & $\begin{array}{l}\text { d) Empati } \\
\text { (Empathy), }\end{array}$ & $\begin{array}{l}\text { 1) Pemahaman } \\
\text { 2) Perhatian }\end{array}$ & $\begin{array}{l}7 \\
8\end{array}$ \\
\hline $\begin{array}{l}\text { Freddy Rangkuti } \\
\text { (2007) }\end{array}$ & $\begin{array}{l}\text { e) Kasat Mata } \\
(\text { Tangible })\end{array}$ & $\begin{array}{l}\text { 1) Penampilan Fisik } \\
\text { 2) Sasaran }\end{array}$ & $\begin{array}{c}9 \\
10\end{array}$ \\
\hline
\end{tabular}

Teknik Analisis Data

\section{Analisis Korelasi Parsial}

Untuk mencari nilai Korelasi

Parsial dengan mengutip pendapat

$$
r=\frac{n \cdot \sum X Y-\sum X \cdot \sum Y}{\sqrt{n\left(\sum X^{2}\right)-\left(\sum X\right)^{2}} \cdot \sqrt{n\left(\sum Y^{2}\right)-\left(\sum Y\right)^{2}}}
$$

Dimana :

$\mathrm{r}=$ Korelasi
Sugiyono (2010 : 210) dalam buku statistik mengenai analisis korelasi Parsial yakni dengan rumus sebagai berikut 


$$
\begin{aligned}
& \mathrm{X}=\text { Variabel Independen } \\
& \mathrm{Y}=\text { Variabel Dependen } \\
& \mathrm{n}=\text { Jumlah Sampel. }
\end{aligned}
$$

Dengan asumsi pada dasarnya nilai (r) dapat bervariasi dari -1 sampai +1. Menurut J Supranto, (2011 : 79) ada tiga (3) kemungkinan hasil yang diperoleh, antara lain :

- Jika nilai $r=-1$ atau mendekati -1 berarti kedua variabel mempunyai pengaruh negatif.

- Jika nilai $r=0$ atau mendekati 0 berarti kedua variabel tidak mempunyai pengaruh.

- Jika nilai $r=1$ atau mendekati 1 berarti kedua variabel mempunyai pengaruh positif.

\section{Koefiseian Determinasi}

Untuk mengetahui seberapa besar pengaruh variabel bebas mempengaruhi variabel terikat, perlu diketahui nilai koefisien determinasi $r^{2}$ karena nilai variabel bebas yang diukur terdiri dari nilai rasio absolute dan nilai perbandingan, kegunaan dari $\mathrm{r}^{2}$ adalah : Untuk mengukur besarnya prosentase dari variabel bebas dengan variabel terikat. Dengan menggunakan rumus :

$$
\mathrm{KD}=\mathbf{r}^{2} \times 100 \%
$$

\section{Analisis Korelasi Linear Berganda}

Guna mengetahui lebih lanjut besarnya "Pengaruh Motivasi Kerja $\left(\mathrm{X}_{1}\right)$ dan Pelatihan $\left(\mathrm{X}_{2}\right)$ terhadap Kualitas Pelayanan Publik (Y)" maka perlu diketahui nilai koefisien Korelasi Berganda nilai (R) dengan menggunakan rumus Korelasi Berganda 2 prediktor menurut Sugiyono (2010 : 218) adalah :

$$
\operatorname{Ry}_{(1.2)}=\frac{b_{1} X_{1} Y+b_{2} X_{2} Y}{\Sigma Y^{2}}
$$

\section{Keterangan :}

Ryx1X2 = Korelasi antara $\mathrm{X}_{1}$ dan $\mathrm{X}_{2}$ secara bersama-sama dengan variabel Y.

ryx1

$=$ Korelasi Product Moment antara $\mathrm{X}_{1}$ terhadap Y

$\mathrm{ry}_{\mathrm{x} 2}=$ Korelasi Product Moment antara $\mathrm{X}_{2}$ terhadap $\mathrm{Y}$

\section{Analisis Regresi Linear Berganda}

Analisis statistik yang digunakan adalah Analisis Regresi Berganda menurut Sugiyono, (2010 : 211) dengan menggunakan rumus persamaan regresinya adalah berikut ini :

$$
\ddot{Y}=a+b_{1} X_{1}+b_{2} X_{2}+\ldots \ldots+b_{n}
$$

$X_{n}$

$$
\begin{aligned}
& \text { Dimana : } \\
& \mathrm{Y}=\text { Kualitas Pelayanan } \\
& \mathrm{X}_{1} \quad=\text { Motivasi Kerja } \\
& \mathrm{X}_{2} \quad=\text { Pelatihan } \\
& \mathrm{b}_{1}, \mathrm{~b}_{2}=\text { Koefisien regresi } \\
& \text { e } \quad=\text { Residual. }
\end{aligned}
$$

\section{Uji Hipotesis}

Perhitungan atau analisis pada penelitian ini memanfaatkan komputer program SPSS Versi 21 for Windows. Statistik uji yang digunakan adalah :

\section{a. Uji t}

Untuk dapat mengetahui 
"Pengaruh Motivasi Kerja $\left(\mathrm{X}_{1}\right)$ dan Pelatihan $\left(\mathrm{X}_{2}\right)$ terhadap Kualitas Pelayanan Publik (Y)" dengan keputusan uji adalah menggunakan uji parsial dengan rumus :

$$
\text { to }=\frac{r \sqrt{n-2}}{\sqrt{1-(r)^{2}}}
$$

\section{Keterangan :}

$$
\begin{aligned}
& \mathrm{R}=\text { Nilai Korelasi Parsial } \\
& \mathrm{N}=\text { Jumlah Sampel. }
\end{aligned}
$$

$\begin{array}{cccc}\text { Uji } & \mathrm{t} & \begin{array}{c}\text { antara } \\ \text { dengan }\end{array} & \text { variabel } \\ \text { independen } & & \text { variabel }\end{array}$ dependen mengunakan keputusan uji sebagai berikut :

- Jika thitung $>t_{\text {tabel }}$ maka Ho ditolak ada pengaruh Signifikan.

- Jika thitung $<\mathrm{t}_{\text {tabel }}$ maka Ho diterima tidak ada pengaruh.

\section{b. Uji F}

Uji F digunakan untuk mengetahui signifikan atau tidaknya variabel indepnden yakni : Motivasi Kerja $\left(\mathrm{X}_{1}\right)$ dan Pelatihan $\left(\mathrm{X}_{2}\right)$ secara simultan terhadap variabel dependen Kualitas Pelayanan Publik (Y) lalu penulis menggunakan rumus :

$$
\mathrm{Fh}=\frac{\mathrm{R}^{2} 1 \mathrm{k}}{\left(1-\mathrm{R}^{2}\right) /(\mathrm{n}-\mathrm{k}-1)}
$$

\section{Keterangan :}

$\mathrm{R}=$ Koefisien Korelasi Ganda

$\mathrm{k}=$ Jumlah Variabel

Independen

$\mathrm{n}=$ Jumlah anggota sampel.

Setelah dilakukan Uji $F_{\text {hitung }}$ penulis akan menggunakan keputusan uji berikut ini :

- Ho = diterima jika $F_{\text {hitung }}>$ dari $F_{\text {tabel }}$ ada pengaruh signifikan antara variabel independen dengan variabel dependen.

- Ho = ditolak jika $F_{\text {hitung }}<$ dari $F_{\text {tabel }}$ tidak ada pengaruh signifikan antara variabel independen dengan variabel dependen.

Penentuan nilai kritis dari nilai Fhitung di lanjutkan dan dikonsultasikan dengan nilai $\mathrm{F}_{\text {tabel. }}$ Untuk derajat bebas (DK) pembilang 2 dan derajat kebebasan penyebut $(\mathrm{n}-\mathrm{k}-1)$ tingkat signifikansinya $(\alpha)$ $5 \%$ maupun $1 \%$.

\section{PEMBAHASAN}

Hasil Analisis Korelasi Pasrial adalah salah satu metode statistik yang digunakan untuk mengetahui tingkat keeratan pengaruh antara variabel independen diantaranya variabel Motivasi Kerja $\left(\mathrm{X}_{1}\right)$, dan variabel Pelatihan $\left(\mathrm{X}_{2}\right)$ terhadap variabel dependen Kualitas Pelayanan Publik (Y) dapat dilihat pada tabel 4.43 berikut ini. 
Tabel 4.43

HASIL ANALISIS KORELASI PARSIAL

Correlations

\begin{tabular}{|c|c|c|c|c|}
\hline & & $\begin{array}{l}\text { Motivasi } \\
\text { Kerja (X1) }\end{array}$ & Pelatihan (X2) & $\begin{array}{l}\text { Kualitas } \\
\text { Pelayanan } \\
\text { Publik }(Y)\end{array}$ \\
\hline Motivasi Kerja (X1) & $\begin{array}{l}\text { Pearson Correlation } \\
\text { Sig. (2-tailed) } \\
\mathrm{N}\end{array}$ & $\begin{array}{r}1 \\
66\end{array}$ & $\begin{array}{r}.813^{\star \star} \\
.000 \\
66\end{array}$ & $\begin{array}{r}.743^{\star *} \\
.000 \\
66\end{array}$ \\
\hline Pelatihan (X2) & $\begin{array}{l}\text { Pearson Correlation } \\
\text { Sig. (2-tailed) } \\
\mathrm{N}\end{array}$ & $\begin{array}{c}.813^{* \star} \\
.000 \\
66\end{array}$ & $\begin{array}{r}1 \\
66\end{array}$ & $\begin{array}{l}.893^{\star \star} \\
.000 \\
66\end{array}$ \\
\hline $\begin{array}{l}\text { Kualitas Pelayanan } \\
\text { Publik (Y) }\end{array}$ & $\begin{array}{l}\text { Pearson Correlation } \\
\text { Sig. (2-tailed) } \\
\mathrm{N}\end{array}$ & $\begin{array}{c}.743^{* *} \\
.000 \\
66\end{array}$ & $\begin{array}{c}.893^{\star \star} \\
.000 \\
66\end{array}$ & $\begin{array}{r}1 \\
\cdot \\
66\end{array}$ \\
\hline
\end{tabular}

${ }^{\star \star}$. Correlation is significant at the 0.01 level (2-tailed).

Dari hasil analsia data-data dengan menggunakan Komputer program Statistical Package for Social Sciences (SPSS) Versi 21 for Windows pada tabel 4.43 tersebut diatas dapat diketahui pengaruh dari masingmasing variabel sebagai berikut :

\section{a. Pengaruh Motivasi Kerja $\left(\mathbf{X}_{1}\right)$ Terhadap Kualitas Pelayanan Publik} (Y)

Dari output komputer program Statistical Package for Social Sciences (SPSS) Versi 21 for Windows yang didapat koefisien korelasi Parsial variabel Motivasi Kerja $\left(\mathrm{X}_{1}\right)$ nilai sebesar 0,743 sehingga dapat disimpulkan bahwa hasil analisis antara variabel Motivasi Kerja $\left(\mathrm{X}_{1}\right)$ terhadap variabel Kualitas Pelayanan Publik (Y) bernilai positif dan pengaruhnya kuat.

Karena nilai tersebut belum menunjukkan besaran pengaruh, maka besar pengaruh tersebut dihitung secara manual dengan menggunakan rumus koefisien determinasi sebagai berikut : $\mathrm{KD}$ $=r^{2} \times 100 \%$. Dimana $r$ adalah nilai hasil analisis koefisien korelasi sebesar sebesar 0,743. Hasil perhitungan selanjutnya sebagai berikut :

$$
\begin{gathered}
\mathrm{KD}=\mathrm{r}^{2} \times 100 \% \quad=0,743^{2} \times 100 \% \\
=0,552 \times 100 \% \\
=55,2 \% .
\end{gathered}
$$

Dengan hasil tersebut diatas dapat dikatakan bahwa variabel Motivasi Kerja $\left(\mathrm{X}_{1}\right)$ terhadap Kualitas Pelayanan Publik (Y) mempunyai pengaruh sebesar 55,2\% dan sisanya sebesar 44,8\% disebabkan oleh faktor-faktor yang lainnya yang tidak diamati oleh penulis.

\section{b. Pengaruh Pelatihan $\left(\mathbf{X}_{2}\right)$ Terhadap Kualitas Pelayanan Publik (Y)}

Dari output komputer program Statistical Package for Social Sciences (SPSS) Versi 21 for Windows yang didapat koefisien korelasi parsial didapat nilai sebesar 0,893 sehingga dapat disimpulkan bahwa hasil analisis antara variabel Pelatihan $\left(\mathrm{X}_{2}\right)$ terhadap variabel Kualitas Pelayanan Publik (Y) bernilai positif dan pengaruhnya sangat kuat. 
Karena nilai tersebut belum menunjukkan besaran pengaruh, maka besar pengaruh tersebut dihitung secara manual dengan menggunakan rumus koefisien determinasi sebagai berikut : KD $=r^{2} \times 100 \%$. Dimana $r$ adalah nilai hasil analisis koefisien korelasi sebesar sebesar 0,893. Hasil perhitungan selanjutnya sebagai berikut :

$$
\begin{gathered}
\mathrm{KD}=\mathrm{r}^{2} \times 100 \% \quad=0,893^{2} \times 100 \% \\
=0,797 \times 100 \% \\
=79,7 \%
\end{gathered}
$$

Dengan hasil tersebut diatas dapat dikatakan bahwa variabel Pelatihan $\left(\mathrm{X}_{2}\right)$ terhadap variabel Kualitas Pelayanan Publik (Y) mempunyai pengaruh sebesar
$79,7 \%$ dan sisanya sebesar $20,3 \%$ disebabkan oleh faktor-faktor yang lainnya yang tidak diamati oleh penulis.

\section{Analisis Korelasi Berganda}

Tujuan analisis korelasi dimasud untuk mengetahui tingkat pengaruh dan signifikan hubungan antara variabel independen yakni variabel dengan variabel depeden yakni variabel (Y) baik secara simultan (bersama-sama) dengan menggunakan komputer program Statistical Package for Social Sciences (SPSS) Versi 21 for Windows adapun hasilnya lihat tabel Model Summary sebagai berikut :

\section{ANALISIS KOEFISIEN KORELASI SECARA BERSAMA-SAMA}

Model Summary

\begin{tabular}{|l|r|r|r|r|r|}
\hline Model & $\mathrm{R}$ & R Square & $\begin{array}{c}\text { Adjusted } \\
\text { R Square }\end{array}$ & $\begin{array}{c}\text { Std. Error of } \\
\text { the Estimate }\end{array}$ & $\begin{array}{c}\text { Durbin- } \\
\text { Watson }\end{array}$ \\
\hline 1 & $.894^{\mathrm{a}}$ & .798 & .792 & 4.44471 & 1.700 \\
\hline
\end{tabular}

a. Predictors: (Constant), Pelatihan (X2), Motivasi Kerja (X1)

b. Dependent Variable: Kualitas Pelayanan Publik (Y)

Berdasarkan pada tabel tersebut diatas hasil analisis variabel Motivasi Kerja $\left(\mathrm{X}_{1}\right)$ dan Pelatihan $\left(\mathrm{X}_{2}\right)$ terhadap variabel Kualitas Pelayanan Publik (Y) yakni model Summary yang menghasilkan nilai $\mathrm{R}$ sebesar 0,894 memiliki nilai positif dan tingkat pengaruh sangat kuat sedangkan nilai $\mathrm{R}$ Square sebesar 0,798 atau $79,8 \%$ hal ini dapat dinyatakan dengan hasil analisa secara bersama-sama variabel Motivasi Kerja $\left(\mathrm{X}_{1}\right)$ dan Pelatihan $\left(\mathrm{X}_{2}\right)$ terhadap variabel Kualitas Pelayanan Publik (Y) memiliki nilai positif dan tingkat pengaruhnya sangat kuat.

Adapun untuk menentukan tinggi rendahnya pengaruh antara variabelvariabel dapat dilihat pada tabel di bawah ini 
NILAI KOEFISIEN KORELASI DAN INTERPRETASI

\begin{tabular}{|c|c|}
\hline \hline Koefisien Korelasi & Interpretasi \\
\hline $0,00-0,199$ & Sangat Rendah \\
\hline $0,20-0,399$ & Rendah \\
\hline $0,40-0,599$ & Sedang \\
\hline $0,60-0,799$ & Kuat \\
\hline $0,80-1,000$ & Sangat Kuat \\
\hline
\end{tabular}

Sumber : Sugiyono, 2010.

\section{Analisis Regresi Berganda}

Hasil analisis regresi berganda dengan menggunakan Komputer program Statistical Package for Social Sciences
(SPSS) Versi 21 for Windows yakni analisis regresi linear berganda sebagai berikut :

\section{ANALISIS REGRESI LINEAR BERGANDA}

\section{Coefficients $\mathrm{s}^{\mathrm{a}}$}

\begin{tabular}{|ll|r|r|r|r|r|}
\hline \multirow{2}{*}{ Model } & \multicolumn{2}{|c|}{$\begin{array}{c}\text { Unstandardized } \\
\text { Coefficients }\end{array}$} & \multicolumn{2}{c|}{$\begin{array}{c}\text { Standardized } \\
\text { Coefficients }\end{array}$} & & \\
\cline { 3 - 5 } & & \multicolumn{1}{|c|}{ B } & Std. Error & \multicolumn{1}{c|}{ Beta } & \multicolumn{1}{c|}{ S } & Sig. \\
\hline 1 & (Constant) & 10.786 & 2.039 & & 5.289 & .000 \\
& Motivasi Kerja (X1) & .446 & .088 & .449 & 2.507 & .014 \\
& Pelatihan (X2) & .825 & .094 & .853 & 8.784 & .000 \\
\hline
\end{tabular}

a. Dependent Variable: Kualitas Pelayanan Publik (Y)

Untuk menentukan nilai persamaan regresi linear bergandanya sebagai berikut $: Y=10,786+0,446 X_{1}+0,825 X_{2}$

Dapat dijelaskan sebagai berikut :

a. Nilai konstanta intersep sebesar 10,786 menyatakan bahwa jika variabel Motivasi Kerja $\left(\mathrm{X}_{1}\right)$ adalah nol variabel Pelatihan $\left(\mathrm{X}_{2}\right)$ nol, maka variabel Kualitas Pelayanan Publik (Y) akan mengalami peningkatan sebesar 10,786.

b. Nilai koefisen regresi variabel Motivasi Kerja $\left(\mathrm{X}_{1}\right)$ terhadap variabel Kualitas Pelayanan Publik (Y) adalah sebesar 0,446. Hal ini berarti jika variabel Motivasi Kerja $\left(\mathrm{X}_{1}\right)$ naik 1 satuan akan meningkatkan variabel Kualitas Pelayanan Publik (Y) sebesar 0,446, dengan asumsi variabel Motivasi Kerja
$\left(\mathrm{X}_{1}\right)$ dan variabel Pelatihan $\left(\mathrm{X}_{2}\right)$ dianggap konstan.

c. Nilai koefisien regresi variabel Pelatihan $\left(\mathrm{X}_{2}\right)$ terhadap variabel Kualitas Pelayanan Publik (Y) adalah sebesar 0,825 . Hal ini berarti jika variabel Pelatihan $\left(\mathrm{X}_{2}\right)$ meningkat 1 satuan maka variabel Kualitas Pelayanan Publik (Y) akan meningkat sebesar 0,825 dengan asumsi variabel Pelatihan $\left(\mathrm{X}_{2}\right)$ dan variabel Motivasi Kerja $\left(\mathrm{X}_{1}\right)$ dianggap konstan.

\section{Hipotesis (Uji t)}

Apakah masing-masing variabel Motivasi Kerja $\left(\mathrm{X}_{1}\right)$ dan variabel Pelatihan $\left(\mathrm{X}_{2}\right)$ secara parsial mempunyai pengaruh bermakna terhadap variabel 
Kualitas Pelayanan Publik (Y) dilakukan pengujian $t_{\text {hitung }}$ dan $t_{\text {tabel. }}$. Untuk hipotesis (Uji t) ini penulis melakukan dengan cara membandingkan antara hasil thitung dengan $t_{\text {tabel }}$ yaitu memiliki nilai masing-masing sebagai berikut :

Tabel 4.47

Hasil Uji $t$ (Perbandingan $t_{\text {hitung }}$ dan $t_{\text {tabel }}$ )

\begin{tabular}{|l|c|c|c|c|}
\hline \multicolumn{1}{|c|}{ Variabel } & Nilai & $\begin{array}{c}\text { Standard } \\
\text { Error }\end{array}$ & $\mathbf{t}_{\text {hitung }}$ & $\mathbf{t}_{\text {tabel }}$ \\
\hline Motivasi Kerja $\left(\mathrm{X}_{1}\right)$ & 0,446 & 0,088 & 2,507 & 1,670 \\
\hline Pelatihan $\left(\mathrm{X}_{2}\right)$ & 0,825 & 0,094 & 8,784 & 1,670 \\
\hline
\end{tabular}

Berdasarkan hasil uji t tersebut di atas, bahwa secara nyata variabel Motivasi Kerja $\left(\mathrm{X}_{1}\right)$ mempunyai pengaruh yang kuat terhadap variabel Kualitas Pelayanan Publik (Y) dimana nilai $t_{\text {hitung }}>$ dari $t_{\text {tabel, }}$ dengan demikian dapat dikatakan bahwa $\mathrm{H}_{0}$ ditolak $\mathrm{H}_{\mathrm{a}}$ diterima. Begitu juga variabel Pelatihan $\left(\mathrm{X}_{2}\right)$ terhadap variabel Kualitas Pelayanan Publik (Y), dimana nilai thitung $>$ dari $t_{\text {tabel, }}$ secara nyata mempunyai pengaruh terhadap variabel Kualitas Pelayanan Publik (Y) dengan demikian dapat dikatakan bahwa $\mathrm{H}_{0}$ ditolak $\mathrm{H}_{\mathrm{a}}$ diterima.

Berikut ini hasil uji t antara variabel Motivasi Kerja $\left(\mathrm{X}_{1}\right)$ terhadap variabel Kualitas Pelayanan Publik (Y), maka dapat dilihat dalam bentuk kurvanya sebagai berikut :

\section{Kurva Uji t Hipotesis Pertama}

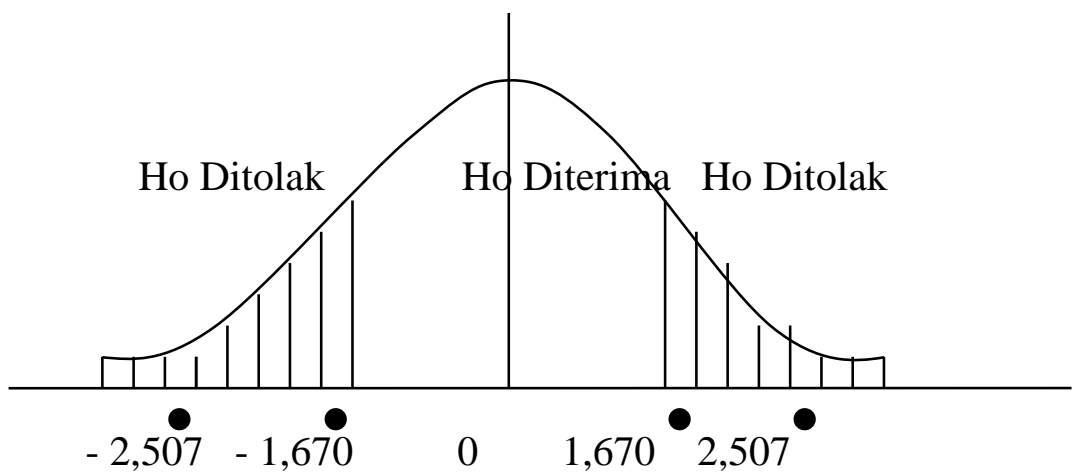

Berdasarkan hasil uji hipotesis yang diperoleh dengan nilai thitung sebesar = $2,507>\mathrm{t}_{0,05(64)}=1,670$, maka $\mathrm{H}_{\mathrm{o}}$ ditolak dan $\mathrm{H}_{\mathrm{a}}$ diterima yang berarti mempunyai cukup bukti bahwa antara variabel Motivasi Kerja $\left(\mathrm{X}_{1}\right)$ terhadap variabel Kualitas Pelayanan Publik (Y) ada pengaruh signifikan.

Berikut ini uji $\mathrm{t}$ antara variabel Pelatihan $\left(\mathrm{X}_{2}\right)$ terhadap variabel Kualitas Pelayanan Publik (Y) maka dapat dilihat dalam bentuk kurvanya sebagai berikut : 


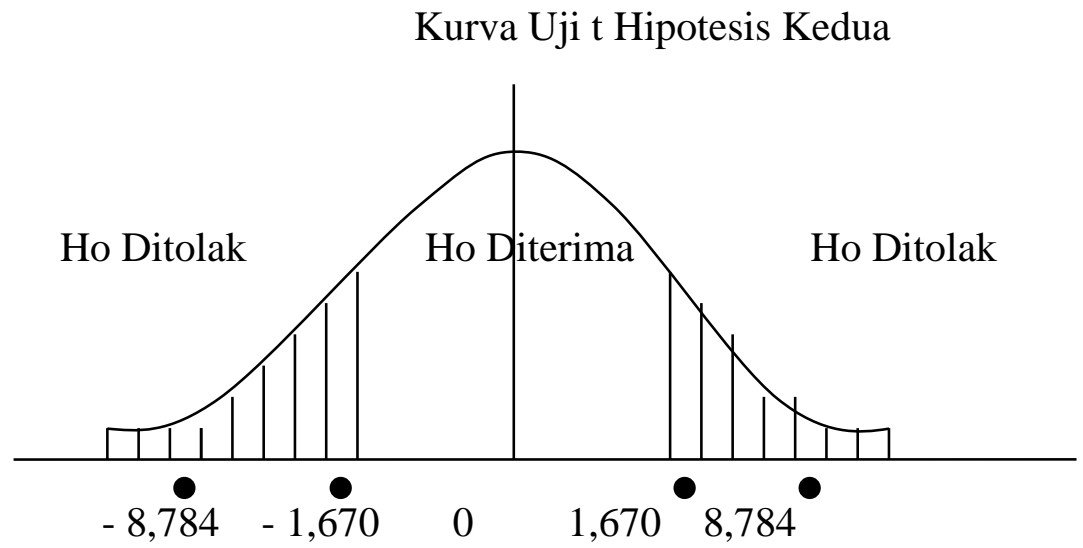

Dari hasil uji hipotesis variabel Pelatihan $\left(\mathrm{X}_{2}\right)$ yang diperoleh yakni karena nilai $\mathrm{t}_{\text {hitung }}=8,784>\mathrm{t}_{0,05}$ (64) $=$ 1,670, maka $\mathrm{H}_{\mathrm{o}}$ ditolak dan $\mathrm{H}_{\mathrm{a}}$ diterima yang berarti mempunyai bukti, bahwa antara variabel Pelatihan $\left(\mathrm{X}_{2}\right)$ dengan variabel Kualitas Pelayanan Publik (Y) ada pengaruh signifikan. Dari hasil uji $\mathrm{t}$ tersebut di atas bahwa hipotesis yang diajukan pada bab terdahulu tinjauan pustaka poin hipotesis ternyata mempunyai cukup bukti kebenarannya.

\section{Uji F (Anova)}

Dari hasil uji secara simultan atau bersama-sama dengan menggunakan Komputer program Statistical Package for Social Sciences (SPSS) Versi 21 for windows. Untuk lebih jelas dapat dilihat pada tabel 4.48 berikut ini :

ANOVA

\begin{tabular}{|ll|r|r|r|r|r|}
\hline \multicolumn{2}{|c|}{} & \multicolumn{1}{c|}{ Sum of } & & & & \\
\hline 1 & Squares & df & Mean Square & F & Sig. \\
\hline & Regression & 4929.227 & 2 & 2464.613 & 124.756 & $.000^{\mathrm{a}}$ \\
& Residual & 1244.591 & 63 & 19.755 & & \\
& Total & 6173.818 & 65 & & & \\
\hline
\end{tabular}

a. Predictors: (Constant), Pelatihan (X2), Motivasi Kerja (X1)

b. Dependent Variable: Kualitas Pelayanan Publik $(Y)$

Dari hasil analisis dengan menggunakan Komputer program Statistical Package for Social Sciences (SPSS) Versi 21 for windows yakni uji ANOVA atau $F_{\text {hitung variabel Motivasi }}$ Kerja $\left(\mathrm{X}_{1}\right)$ dan Pelatihan $\left(\mathrm{X}_{2}\right)$ terhadap variabel Kualitas Pelayanan Publik (Y) di peroleh nilai sebesar 124,756 dimana lebih besar dari $F_{\text {tabel }}(65)$ sebesar 2,750 dengan tingkat signifikan sebesar 0,000 karena
$0,000<0,05$, maka dapat dikatakan secara bersama-sama berpengaruh positif.

\section{KESIMPULAN DAN SARAN}

1. Berdasarkan hasil analisis koefisien korelasi parsial bernilai positif antara variabel Motivasi Kerja terhadap variabel Kualitas Pelayanan Publik diperoleh nilai sebesar 0,743 sehingga dapat disimpulkan bahwa pengaruhnya 
kuat. Dibuktikan melalui hasil uji hipotesis yang diperoleh dengan nilai $t_{\text {hitung }}$ sebesar $=2,507>\mathrm{t}_{0,05}(64)=$ 1,670, maka $\mathrm{H}_{\mathrm{o}}$ ditolak dan $\mathrm{H}_{\mathrm{a}}$ diterima yang berarti mempunyai cukup bukti bahwa antara variabel Motivasi Kerja terhadap variabel Kualitas Pelayanan Publik ada pengaruh yang signifikan.

2. Berdasarkan hasil analisis koefisien korelasi parsial bernilai positif antara variabel Pelatihan terhadap variabel Kualitas Pelayanan Publik diperoleh nilai sebesar 0,893 sehingga dapat disimpulkan pengaruhnya sangat kuat. Dibuktikan melalui hasil uji hipotesis variabel Pelatihan yang diperoleh yakni karena nilai $t_{\text {hitung }}=8,784>\mathrm{t}_{0,05}$ (64) $=1,670$, maka $\mathrm{H}_{\mathrm{o}}$ ditolak dan $\mathrm{H}_{\mathrm{a}}$ diterima yang berarti mempunyai bukti, bahwa antara variabel Pelatihan terhadap variabel Kualitas Pelayanan Publik ada pengaruh signifikan.

3. Berdasarkan hasil analisis secara simultan variabel Motivasi Kerja dan Pelatihan terhadap Kualitas Pelayanan Publik yang menghasilkan model Summary atau nilai R sebesar 0,894 memiliki nilai positif dan tingkat pengaruh sangat kuat sedangkan nilai R Square sebesar 0,798 atau 79,8\% hal ini dinyatakan kedua variabel independen tersebut dapat mempengaruhi variabel dependen sebesar 79,8\%. Dibuktikan dengan uji $F_{\text {hitung }}$ diperoleh nilai sebesar 124,756 dimana lebih besar dari $F_{\text {tabel }}$ (65) sebesar 2,750 dengan tingkat signifikan sebesar 0,000 karena 0,000 $<0,05$, maka dapat dikatakan variabel Motivasi Kerja dan Pelatihan secara bersama-sama berpengaruh positif terhadap Kualitas Pelayanan Publik pada Rumah Sakit dr. Esnawan Antariksa Hanud Halim Perdanakusuma.

\section{Saran}

Berdasarkan pada kesimpulan tersebut di atas, maka berikut ini penulis akan memberikan beberapa saran. Adapun saransaran yang dapat penulis dikemukakan adalah sebagai berikut :

1. Pimpinan Rumah Sakit dr. Esnawan Antariksa Lanud Halim Perdanakusuma hendaknya terus dapat memelihara dan meningkatkan motivasi kerja bila perlu terus di tingkatkan lagi motivasi kerjanya agar di masa yang akan datang dapat mempengaruhi tingkat kualitas pelayanan publik secara optimal.

2. Pimpinan Rumah Sakit dr. Esnawan Antariksa Lanud Halim Perdanakusuma hendaknya harus meningkatkan Pelatihan baik mengenai kesehatan maupun pelayanan publik-nya apa bila hal tersebut dapat berjalan dengan baik, maka secara nyata di masa yang akan datang dapat terus meningkatkan kualitas pelayanan publik di rumak sakit ini.

3. Seluruh pegawai Rumah Sakit dr. Esnawan Antariksa Lanud Halim Perdanakusuma hendaknya terus membenahi motivasi kerjanya dan mengikuti program pelatihan secara keseluruhan baik pelatihan bidang kesehatan maupun pelayanan publik yang lebih berkualitas sebagaimana yang diharapkan pimpinan dan semuah pihak. 


\section{DAFTAR PUSTAKA}

Abraham Maslow dalam Anwar Prabu

Mangkunegara, 2005. Teori

Motivasi, Badan Penerbit PT.

Remaja Rosdakarya, Bandung.

Abraham Maslow dalam Susilo Martoyo, 2005. Teori Motivasi, Badan Penerbit PT. Remaja Rosdakarya, Bandung.

Abraham Maslow dalam Sondang P. Siagian, 2000, Manajemen Sumber Daya Manusia, Badan Penerbit ALFABETA Bandung.

Anwar Prabu Mangkunegara, 2009. Manajemen Sumber Daya Manusia Perusahaan, Badan Penerbit, PT. Remaja Rosdakarya, Bandung.

Arikunto, Suharsimi, 2008. Prosedur Penelitian Suatu Pendekatan Praktek, Rineka Cipta. Jakarta.

Bambang Istianto, 2011, Manajemen Pemerinthan dalam Prespektif Pelayanan Publik, Badan Penerbit Mitra Wacana Media, Jakarta.

Bedjo Siswanto Sastrohadiwiryo, 2005, Manajemen Sumber Daya Manusia, Badan Penerbit Grasindo Gramedia Jakarta.

Faustino Cardoso Gomes, 2008, Manajemen Sumber Daya Manusia, Badan Penerbit Andi,. Yogyakarta.

Feisal Tamin, 2009, Reformasi Pelayanan Publik: Teori, Kebijakan, dan Implementasi. Badan Penerbit PT Bumi Aksara. Jakarta.

Freddy Rangkuti, 2007, , Teknik Mengukur dan Strategi Meningkatkan Kepuasan Pelangan”, Badan
Penerbit PT Gramedia Pustaka Utama, Jakarta.

Gary Dessler, 2007. Manajemen Sumber Daya Manusia. Edisi Bahasa Indonesia Jilid 2. Badan Penerbit PT. Prenhallindo. Jakarta.

George R. Terry dalam Winardi, 2008, Motivasi dan Disiplin dalam Manajemen. Badan Penerbit Raja Grafindo Persada, Jakarta.

Gouzali Saydam, 2006, "Manajemen Sumber Daya Manusia jilid 2", Badan Penerbit PT. Gunung Agung, Jakarta

Hasibuan, Malayu S.P. 2007, Manajemen Sumber Daya Manusia, Badan Penerbit PT. Gunung Agung, Jakarta.

Heidjrachman dan Suad Husnan, 2008, Manajemen Personalia, Edisi IV, Cetakan ke-7, Penerbit FE-UGM, Yogyakarta.

Hadari Nawawi , 2005. Metode Penelitian Bidang Sosial, Badan Penerbit Gajah Mada Universitas Press, Yogyakarta.

Husein Umar, 2005. Riset Sumber Daya Manusia Dalam Organisasi, Badan Penerbit Rajawali Pers. Jakarta.

I.G, Wursanto 2009, Manajemen Kepegawaian I, Badan Penerbit Kanisius, Yogyakarta

J. Supranto, 2011. Metodologi Ramalan Kuantitatif untuk Perencanaan Ekonomi dan Bisnis, Badan Penerbit PT. Rineka Cipta. Jakarta.

M. Manullang, 2008, Dasar-Dasar Manajemen, Badan Penerbit Ghalia Indonesia, Jakarta. 
Motivasi Dan Pelatihan Kerja Sebagai Determinan Dalam Kualitas

Pelayanan Publik Pada Rumah Sakit Dr. Esnawan Antariksa

Lanud Halim Perdanakusuma

ISSN : 1412-629X

Mc. Gregor dalam Malayu SP. Hasibuan, Manajemen, 2007, Sumber Daya Manusia, Badan Penerbit PT. Bumi Aksara, Jakarta.

Mohkijat, 2008, Pengembangan Manajemen dan Motivasi, Badan Penerbit Pionis Jaya Bandung.

Moenir dalam Tangkilisan, Hessel Nogi S. 2005. Kebijakan Publik Yang Membumi. Badan Penerbit Lukman Offset \& YPAPI. Yogyakarta.

Nana Sudjana, 2004, Teknologi Pengajaran, Badan Penerbit Sinar Baru Algesindo. Bandung.

Ratminto \& Atik, Septi Winarsih, 2010, Manajemen Pelayanan, Badan Penerbit Pustaka Belajar, Yogyakarta.

Riduwan, 2007, Skala Pengukuran Variabelvariabel Penelitian, Badan Penerbit, ALFABETA, Bandung.

Santoso, Singgih, 2006. SPSS Versi 21 Mengolah Data Statistik Secara Profesional, Badan Penerbit PT. Elex Media Komputindo. Jakarta.

Sedarmayanti, 2008. Tata Kerja dan Produktivitas Kerja, Badan Penerbit Mandar Maju Bandung.

Soewarno Handajaningrat, 2004, Pengantar Studi Ilmu Administrasi dan Manajemen, Penerbit Gunung Agung. Jakarta.

Sondang P. Siagian, 2007. Manajemen Sumber Daya Manusia, Badan Penerbit Bumi Aksara, Jakarta.

Sonny Harsono, 2004, Skala Pengukuran Variabel-variabel Penelitian, Badan Penerbit ALFABETA. Bandung.

Sugiyono, 2010. Metode Penelitian Bisnis, Badan Penerbit ALFABETA Bandung.

Susilo Martoyo, 2005, Manajemen Sumber Daya Manusia, Edisi 3, BPFE, Yogyakarta.

Stoner dan Freeman, 2009, Management, Prentice-Hall, Inc: Englewood-Cliffs.

Tangkilisan, 2009, Pendekatan Manusiawi dan Organisasi Terhadap Pembinaan Kepegawaian, Badan Penerbit Gunung Agung. Jakarta.

T. Hani Handoko, 2007, Manajemen Personalia dan Sumberdaya Manusia. Badan Penerbit BPFE Yogyakarta.

Tjahya Supriatna, 2010, Manajemen Kepemimpinan, dan Sumberdaya Aparatur, Badan Penerbit. CV. Indra Prahasta, Bandung.

Undang-Undang Republik Indonesia Nomor 25 Tahun 2009 tentang Pelayanan Publik.

Zeitham, dan Berry dalam Freddy Rangkuti,. 2007, Teknik Mengukur dan Strategi Meningkatkan Kepuasan Pelangan”, Badan Penerbit PT Gramedia Pustaka Utama, Jakarta. 